\title{
Interferon- $\gamma$ enhances the antifibrotic effects of pirfenidone by attenuating IPF lung fibroblast activation and differentiation
}

\author{
Tuong N. Vu ${ }^{1 \dagger}$, Xuesong Chen ${ }^{1 \dagger}$, Hussein D. Foda ${ }^{1,2}$, Gerald C. Smaldone ${ }^{1}$ and Nadia A. Hasaneen ${ }^{1,2^{*}}$
}

\begin{abstract}
Background: Idiopathic pulmonary fibrosis (IPF) pathogenesis involves multiple pathways, and combined antifibrotic therapy is needed for future IPF therapy. Inhaled interferon- $\gamma$ (IFN- $\gamma$ ) was recently shown to be safe and without systemic effects in patients with IPF.

Aim: To examine the in vitro effects of individual and combined treatment with IFN- $\gamma$ and pirfenidone (PFD) on normal and IPF fibroblast activation and extracellular matrix remodeling after TGF- $\beta 1$ and PDGF-BB stimulation.

Methods: IPF and normal human lung fibroblasts (NHLF) were treated with IFN- $\gamma$, PFD or a combination of both drugs in the presence of either TGF- $\beta 1$ or PDGF-BB. The effects of TGF- $\beta 1$ and PDGF-BB treatment on cell viability, proliferation, differentiation and migration were examined. The expression of collagen 1, matrix metalloproteinases (MMPs) and tissue inhibitors of MMP (TIMPs) was analyzed using GPCR, Western blotting and gelatin zymography. Total collagen content in conditioned media was also measured using a Sircol assay.

Results: Compared to that of PFD, the effect of IFN- $y$ in downregulating normal and IPF lung fibroblast differentiation to myofibroblasts in response to TGF- $\beta 1$ was more potent. Importantly, the combination of IFN- $\gamma$ and PFD had a possibly synergistic/additive effect in inhibiting the TGF- $\beta 1$ - and PDGF-BB-induced proliferation, migration and differentiation of normal and IPF lung fibroblasts. Furthermore, both drugs reversed TGF- $\beta 1$-induced effects on MMP-1, $-2,-3,-7$, and -9 , while only PFD promoted TIMP-1 and-2 expression and release.
\end{abstract}

Conclusions: Our findings demonstrate that the antifibrotic effects of IFN- $\gamma$ and PFD on normal and IPF lung fibroblasts are different and complementary. Combination therapy with inhaled IFN- $\gamma$ and PFD in IPF is promising and should be further explored in IPF clinical trials.

Keywords: Fibroblast activation, IPF, IFN- $\gamma$, Pirfenidone, MMPs, TIMPs

\section{Introduction}

Idiopathic pulmonary fibrosis (IPF) is the most common form of idiopathic interstitial pneumonia, and patients with IPF exhibit poor survival and have limited therapeutic options [1,2]. Dysregulated wound healing is thought to cause the development of fibrosis through excess fibroblast

\footnotetext{
* Correspondence: Nadia.Hasaneen@stonybrookmedicine.edu

${ }^{\dagger}$ Tuong N. Vu and Xuesong Chen contributed equally to this work.

'Pulmonary, Critical Care and Sleep Division, Department of Medicine, Stony Brook Medicine, Health Science Center, State University of New York at Stony Brook, HSC T17 Room 040, Stony Brook, NY 11794-8172, USA

2Department of Medicine and Research, VAMC Northport, Stony Brook, NY, USA
}

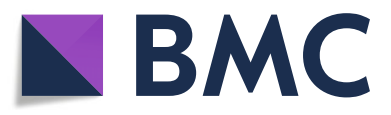

(c) The Author(s). 2019 Open Access This article is distributed under the terms of the Creative Commons Attribution 4.0 International License (http://creativecommons.org/licenses/by/4.0/), which permits unrestricted use, distribution, and

reproduction in any medium, provided you give appropriate credit to the original author(s) and the source, provide a link to the Creative Commons license, and indicate if changes were made. The Creative Commons Public Domain Dedication waiver (http://creativecommons.org/publicdomain/zero/1.0/) applies to the data made available in this article, unless otherwise stated.

proliferation, migration, and differentiation to myofibroblasts and extracellular matrix (ECM) deposition [3]. In the IPF lung, aggregates of proliferating fibroblasts and myofibroblasts, termed "fibroblast foci", are a key histopathological finding that indicates ongoing fibrosis [4]. Targeting the inhibition of key fibroblast activities may lead to novel therapeutic approaches for IPF [5-7]. ECM remodeling and degradation is maintained by the balance of matrix metalloproteinases (MMPs) and tissue inhibitors of matrix metalloproteinase (TIMPs) [8-13]. MMPs not only degrade all the components of the extracellular matrix, but they are also able to release, cleave and activate a wide 
range of growth factors, cytokines, chemokines and cell surface receptors affecting numerous fibroblasts functions, including adhesion, proliferation, differentiation, recruiting and transmigration, and apoptosis [11, 14-16].

Given the complex pathogenesis of IPF leading to lung fibrosis, which involves multiple coactivated pathways, combination therapy may be a rational treatment approach in IPF patients. Treatment of IPF with pirfenidone or nintedanib does not stop ongoing fibrosis and is limited to patients with only mild to moderate disease [17]. Pirfenidone (PFD) is a pleiotropic molecule that inhibits TGF $-\beta$, collagen synthesis, and fibroblast proliferation and mediates tissue repair [18-20]. The molecular mechanisms responsible for the antifibrotic action of PFD are still under study.

Interferon- $\gamma($ IFN- $\gamma)$ is a pleiotropic cytokine with antiviral, antibacterial, antitumor, and pro-inflammatory properties that also has antifibrotic activities [21]. Because of the latter, IFN- $\gamma$ is a potential effective biological agent to treat not only lung fibrosis but also liver and renal fibrosis [22-26]. Microarray analysis of the lung fibroblasts from fibrotic lungs showed the strong suppression of IFN- $\gamma$-stimulated genes [27]. We recently demonstrated that inhaled IFN- $\gamma$ in IPF patients is safe with no systemic side effects, an effect very different from that of systemic IFN- $\gamma$, which causes generalized systemic side effects [21]. Furthermore, we found that inhaled IFN- $\gamma$ was associated with a significant improvement in lung diffusion capacity $[24,28,29]$.

The present study aims to examine the in vitro effect of individual and combined treatment with IFN- $\gamma$ and PFD on the activation of NHLF and IPF fibroblasts and ECM remodeling after TGF- $\beta 1$ and PDGF-BB stimulation.

Here, we show that IFN- $\gamma$ treatment attenuates normal and IPF fibroblast differentiation to the myofibroblast phenotype in vitro more effectively than PFD, illuminating a potential therapeutic strategy. Furthermore, IFN- $\gamma$ in combination with PFD has a possibly synergistic/additive effect by inhibiting the activation and differentiation of NHLF and IPF lung fibroblasts possibly by altering the balance of MMPs and TIMPs.

\section{Methods}

\section{Cell culture}

A normal human lung fibroblast (NHLF) cell line (cat \# CC2512) was purchased from Lonza (Lonza, Walkersville, MD, USA). We used 3 different batches of NHLF cells collected from 3 different donors as follows: Batch \# 0000343490 was collected from a 24-year-old female; batch \# 0000369145 was collected from a 43-year-old male and batch \# 0000608197 was collected from a 67year-old male. NHLFs were cultured in fibroblast growth medium (FGM-2) (Lonza), and cells at passage 3 to 7 were used for all experiments. Three human IPF lung fibroblast cell lines (CCL-134 and CCL-191) were purchased from American Type Culture Collection (ATCC) (ATCC, Manassas, VA, USA), and IPF lung fibroblasts (cat \# CC7231) purchased from Lonza at passage 2 to 5 were used for all experiments. IPF lung fibroblasts from ATCC were cultured in F12K medium, while those from Lonza were cultured in FGM-2 (Lonza). Early passages of IPF fibroblasts were used in this study as IPF-derived fibroblasts are known to display morphological features of replicative senescence even at early passage, unlike age-matched control fibroblasts at the same passage [30, 31]. Human recombinant IFN- $\gamma$ (Sigma-Aldrich, St. Louis, USA), PFD (TCI America, Montgomeryville, PA), TGF- $\beta 1$ (Cell Signaling Technology, Danvers, USA) and PDGF-BB (R\&D Systems, Minneapolis, USA) were used in our experiments.

\section{Treatment of IPF fibroblasts and NHLFs}

Lung fibroblasts were seeded at a density of 20,000-25, 000 cells $/ \mathrm{cm}^{2}$, followed by starvation for $2 \mathrm{~h}$ in serumfree medium (SFM). The lung fibroblasts were subsequently treated with or without TGF- $\beta 1(2.5 \mathrm{ng} / \mathrm{ml})$ or PDGF-BB (20 ng/ml) with either IFN- $\gamma(10-40 \mathrm{ng} / \mathrm{ml})$, PFD $(100-500 \mu \mathrm{g} / \mathrm{ml})$ or both IFN- $\gamma /$ PFD in serum-free media supplemented with $0.1 \%$ BSA to provide a protein source to support cell growth. We did not use serum in culture media because it has a mitogenic effect on fibroblasts. Previous reports showed that lung fibroblasts survived in serum-free medium and sustain an increase in cell number after 2 days of starvation in SFM secondary to the autocrine secretion of various mediators, including PDGF, that could influence proliferation and the synthetic activity of fibroblasts [32, 33]. IFN- $\gamma$ was diluted to its final concentration in PBS. Cells received daily treatment with IFN- $\gamma$ at the indicated doses because IFN- $\gamma$ activity is stable for only $18 \mathrm{~h}$ in culture medium. PFD was dissolved in dimethyl sulfoxide (DMSO). The final DMSO concentration in the medium was always $1 \%$.

\section{LDH cytotoxicity assay}

Following treatment with different concentrations of PFD $(100-500 \mu \mathrm{g} / \mathrm{ml})$ and IFN- $\gamma(10-40 \mathrm{ng} / \mathrm{ml})$ at different time periods, the release of lactate dehydrogenase (LDH) was evaluated by the Colorimetric Cytotoxicity Detection Kit (BioVision Inc., Milpitas, CA, USA) according to the manufacturer's instructions. Cytotoxicity (cell necrosis) was indicated as the percentage of LDH release calculated as the ratio between the mean absorbance of treated cultures minus the absorbance of untreated control cells and the mean absorbance of the highest value from the positive control (maximum LDH release by cell lysis) minus the absorbance of untreated cultures. 
Fibroblast proliferation studies Cell titer $96^{\circledR}$ non-radioactive cell proliferation assay NHLFs and IPF fibroblasts $\left(5 \times 10^{4}\right)$ seeded on 24-well plates were grown overnight in serum-containing medium. On the following day, cells were switched to SFM supplemented with $0.1 \%$ BSA and treated with TGF- $\beta 1$ ( $2.5 \mathrm{ng} /$ $\mathrm{ml})$ or PDGF-BB $(20 \mathrm{ng} / \mathrm{ml})$ and different concentrations of IFN $-\gamma$ and PFD for 1,3 or 5 days. After incubation, cell proliferation was assessed using the Cell Titer $96^{\circ}$ Non-Radioactive Cell Proliferation Assay kit obtained from Promega Corporation (Promega Corp., Madison, WI, USA). It is basically a modified MTT assay that demonstrates less than a $5 \%$ difference in cell proliferation compared to $\left[{ }^{3} \mathrm{H}\right]$-thymidine incorporation as per the Promega and our previous laboratory experience $[34,35]$. The medium was replaced with fresh growth medium and dye solution, and cells were incubated at $37^{\circ} \mathrm{C}$ for $2 \mathrm{~h}$. After the addition of solubilization/stop solution, cells were incubated for another $1.5 \mathrm{~h}$ at $37^{\circ} \mathrm{C}$. The absorption of $100 \mu \mathrm{l}$ aliquots in a Corning 96-well flat transparent plate at $570 \mathrm{~nm}$ was obtained using a plate reader.

\section{Direct cell counts}

NHLFs and IPF fibroblasts $\left(5 \times 10^{4}\right)$ seeded on 24-well plates were grown overnight in serum-containing medium. On the following day, cells were switched to SFM supplemented with $0.1 \%$ BSA and treated with PDGF-BB (20 ng/ $\mathrm{ml}$ ) and different concentrations of IFN- $\gamma$ and PFD for 1 or 3 days. At the end of the experiments, the cells were detached from the plate using BD cell detachment solution (Thermo-Fisher Scientific, Waltham, MA, USA). The cell number was counted by a Cellometer ${ }^{\mathrm{rm}}$ Auto 2000 cell counter (Nexcelom Bioscience, Lawrence, MA, USA). Cell viability was determined manually by counting cells after trypan blue staining using a Neubauer hematocytometer and an automated Cellometer.

\section{Migration assay using a modified Boyden chamber assay} NHLFs and IPF fibroblasts were assessed for their ability to migrate in the presence PDGF-BB $(20 \mathrm{ng} / \mathrm{ml})$ using a modified Boyden chamber assay. The migration assays were performed with 24-well tissue culture Transwell plates (Costar, Corning, NY, USA) composed of polycarbonate membranes with $8 \mu \mathrm{m}$ pores. Lung fibroblasts were seeded on the upper chambers of the Transwells at $1 \times 10^{5}$ cells in $100 \mu \mathrm{l}$ of DMEM containing $0.1 \%$ BSA and either IFN- $\gamma(10-40 \mathrm{ng} / \mathrm{ml})$, PFD $(100-500 \mu \mathrm{g} / \mathrm{ml})$ or both IFN- $\gamma /$ PFD. PDGF-BB $(20 \mathrm{ng} / \mathrm{ml})$ was added to the lower chambers. The Transwells were incubated for $24 \mathrm{~h}$. at $37^{\circ} \mathrm{C}$ in a $\mathrm{CO}_{2}$ incubator. The number of cells that migrated to the lower surface of the membrane was counted under 200× magnification. Ten random high- power fields were counted per sample. Each group was run in triplicate.

\section{Sircol assay}

Confluent serum-deprived fibroblasts were stimulated with TGF- $\beta 1(2.5 \mathrm{ng} / \mathrm{ml})$ and incubated in the presence of either IFN- $\gamma$, PFD or both for the indicated time periods. Soluble collagen secretion (collagens type I to V) in the conditioned media was determined using a Sircol ${ }^{\mathrm{Tm}}$ Assay kit (Biocolor; Carrick Fergus, UK) according to the manufacturer's instructions.

\section{Western blotting}

The protein concentrations of the cell lysates were determined by BCA assay. Equal amounts of proteins $(20 \mu \mathrm{g})$ from cell lysates were resolved by $8-16 \%$ SDS-PAGE and transferred onto a nitrocellulose membrane (Amersham Biosciences, Pittsburgh, USA). After blocking with 5\% milk, the membranes were incubated with primary antibodies overnight at $4{ }^{\circ} \mathrm{C}$ followed by incubation with horseradish peroxidase-conjugated secondary antibodies and detection by use of an enhanced chemiluminescence detection system (Amersham Bioscience, Pittsburgh, USA). Primary antibodies included mouse monoclonal anti- $\alpha$-SMA (1: 10000 dilution, Sigma-Aldrich, St. Louis, USA); rabbit polyclonal anti-MMP-1, MMP-3 and MMP-7 (1:1000 dilution, Sigma-Aldrich, St. Louis, USA); and $\beta$-tubulin (1:1000 dilution; Cell Signaling Technology, Danvers, USA). Bands were digitalized, and their densities were quantified using image analysis software. The results are expressed as a ratio of band density to total $\beta$-tubulin density.

\section{Gelatin zymography}

Gelatin zymography of conditioned media was performed as described previously [34]. Briefly, conditioned media from the different treatment conditions were diluted 1:1 in nonreducing sample buffer and separated on 10\% SDS polyacrylamide gels containing $0.1 \%$ gelatin (ThermoFisher Scientific, Waltham, MA USA) for $150 \mathrm{~min}$ at 125 $\mathrm{V}$. SDS was removed by incubation with renaturing buffer (2.5\% Triton X-100 diluted in water) for $30 \mathrm{~min}$ at room temperature. The gels were washed for $30 \mathrm{~min}$ in developing buffer (Thermo-Fisher Scientific, Waltham, MA USA) and then incubated overnight at $37^{\circ} \mathrm{C}$ in fresh developing buffer. Finally, the gels were stained with Coomassie blue. Zones of enzymatic (gelatinolytic) activity were characterized by the absence of Coomassie blue staining.

\section{RNA extraction and qPCR}

RNAs were extracted from IPF and normal lung fibroblasts $24 \mathrm{~h}$ and $72 \mathrm{~h}$ after TGF- $\beta 1$ treatment with either IFN- $\gamma$, PFD or both using RNeasy mini kits (Qiagen; Valencia, CA, USA) according to the manufacturer's instructions. The RNAs were reverse transcribed into 
cDNAs, which were subjected to qPCR analyses using primer pairs specific to each of the following genes: COL1A1, ACTA2, MMP1, MMP3, MMP7, MMP8, MMP9, TIMP1, TIMP2 and YWHAZ (TaqMan ${ }^{\text {Tix }}$ Gene Expression Assay (FAM), Thermo-Fisher Scientific, Waltham, MA USA). qPCR was performed on an ABI Prism 7000 sequence detection system, and mRNA levels for each gene were analyzed with ABI Prism 7000 software (Applied Biosystems, Waltham, MA USA). Relative quantification of each target gene was performed using the comparative CT $\left(2^{-\Delta \Delta \mathrm{CT}}\right)$ method with YWHAZ (tyrosine 3 monooxygenase/tryptophan 5-monooxygenase activation protein, zeta polypeptide) used as a housekeeping gene for the normalization of mRNA expression levels as reported in previous studies $[36,37]$. Data were plotted as $2^{-\Delta \Delta C T}$ (mean fold change) using Graph Pad prism software.

\section{Statistical analysis}

All results are reported as the mean \pm SEM. Data from image analysis are shown as representative immunoblots and as the means \pm SEMs after densitometric image analysis. A paired t-test was used for statistical analysis between 2 groups, and ordinary one-way ANOVA followed by Tukey's multiple comparisons test using GraphPad Prism 8 software were used for comparisons between groups to assess differences among conditions. Significance was indicated when ${ }^{*} p<0.05$.

\section{Results}

IFN- $\gamma$ and PFD attenuate the proliferation of NHLFs and IPF fibroblasts in response to TGF- $\beta 1$ and PDGF-BB

For in vitro experiments, we selected a range of IFN- $\gamma$ $(10-40 \mathrm{ng} / \mathrm{mL})$ and PFD $(100-500 \mu \mathrm{g} / \mathrm{mL})$ concentrations similar to those used in published studies [38-42]. NHLFs and IPF fibroblasts derived from different cell lines and from different batches were used in all experiments. NHLFs and IPF fibroblasts were incubated with INF- $\gamma$, PFD and a combination of IFN- $\gamma /$ PFD in the presence of TGF $-\beta 1$ $(2.5 \mathrm{ng} / \mathrm{mL})$ or PDGF-BB $(20 \mathrm{ng} / \mathrm{ml})$ for 1,3 and 5 days. Initially, cell viability was measured with an LDH release cytotoxicity assay, Trypan blue staining and automated cell counting using a Cellometer Auto 2000 in some experiments. IFN- $\gamma$, PFD or both at the concentrations tested had no cytotoxic effects on NHLFs and IPF fibroblasts for a treatment period of 1,3 and 5 days (Fig. 1a \& b).

Next, NHLF and IPF fibroblast cell proliferation was examined using a Cell Titer $96^{\circ}$ Non-Radioactive Proliferation Assay (Promega Corp., Madison, USA) or automated cell counting. As shown in Fig. 2a \& b, TGF- $\beta 1$-induced proliferation of NHLFs and IPF lung fibroblasts was significantly reduced by IFN- $\gamma(10-40 \mathrm{ng} / \mathrm{ml})$ and PFD $(300-500 \mu \mathrm{g} / \mathrm{ml})$ in a dose-dependent manner after 1,3 and 5 days ( $p=0.0002$, Fig. $2 \mathrm{a} \& p=0.014$ Fig. $2 \mathrm{~b})$. While no significant difference in cell proliferation was noted between IFN- $\gamma$ and PFD treatment, the combination of both drugs significantly inhibited the TGF- $\beta 1$-induced proliferation of NHLFs and IPF fibroblasts compared to individual drugs (Fig. 2a \& b).

When $20 \mathrm{mg} / \mathrm{ml}$ PDGF-BB was used as a mitogen, as shown in Fig. 2c-f, both IFN- $\gamma$ and PFD significantly inhibited the PDGF-BB-induced proliferation of NHLFs and IPF fibroblasts. Furthermore, a significant difference in the effect of individual and combined treatment with both IFN- $\gamma$ and PFD was observed $(p<0.01$, Fig. $2 \mathrm{c}-\mathrm{f})$. Interestingly, combination therapy with both IFN- $\gamma$ and PFD, especially at high doses, attenuated cell proliferation
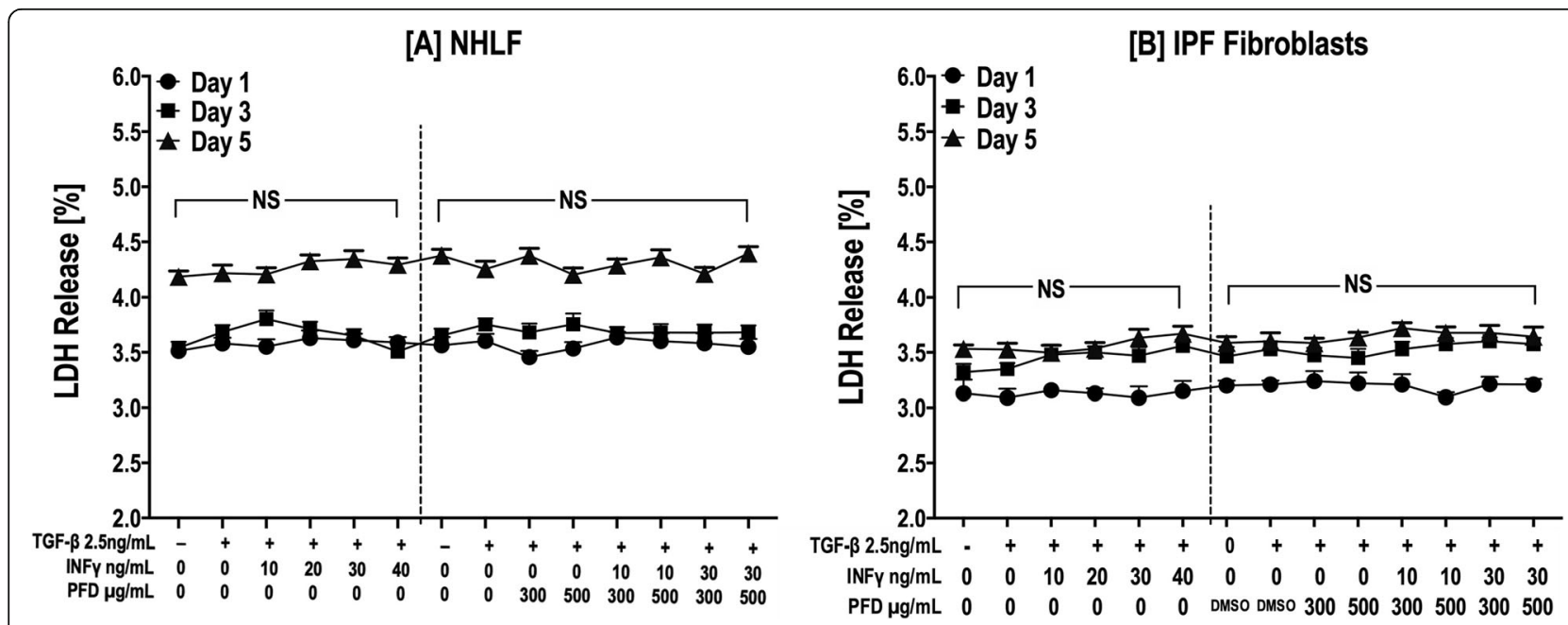

Fig. 1 Effect of IFN- $\gamma$, PFD and their combination on the viability of NHLFs and IPF fibroblasts. NHLFs (a) and IPF fibroblasts (b) were incubated with INF- $\gamma[10-40 \mathrm{ng} / \mathrm{mL}]$, PFD [300-500 $\mu \mathrm{g} / \mathrm{ml}]$ and a combination of NF- $\gamma /$ PFD in the presence of TGF $-\beta 1[2.5 \mathrm{ng} / \mathrm{mL}]$ for 1,3 and 5 days. Cell viability was determined by LDH release cytotoxicity assay. Data are presented as the mean \pm SEM of the \% LDH released to that of control samples in three different experiments, with each experiment run in duplicate. [NS] comparing treatment to control media or control media with vehicle [DMSO] 


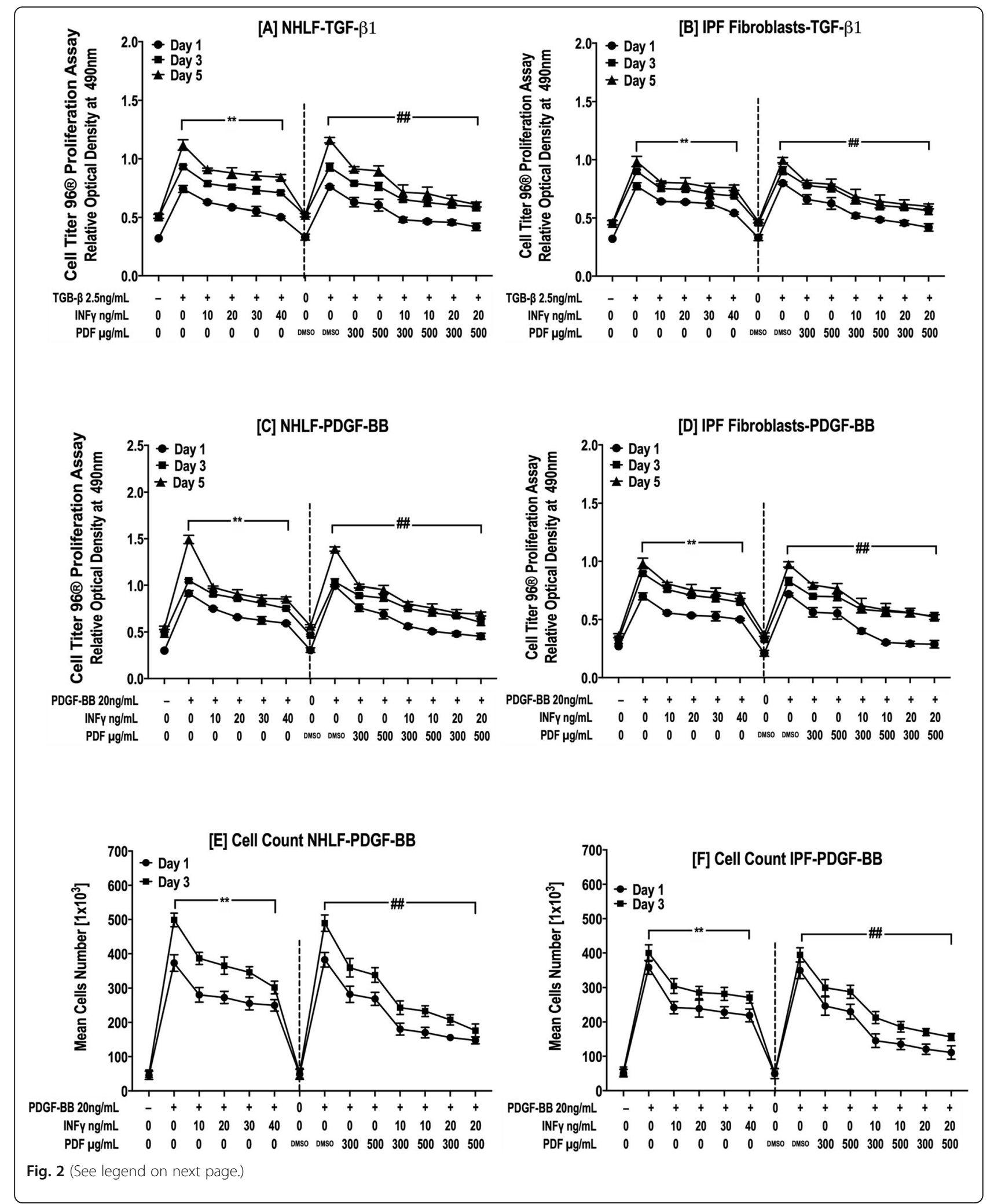


(See figure on previous page.)

Fig. 2 INF- $\gamma$ and PFD inhibit the proliferation of NHLFs and IPF fibroblasts in response to TGF- $\beta 1$ and PDGF-BB. NHLFs and IPF fibroblasts were stimulated with either TGF- $\beta 12.5 \mathrm{ng} / \mathrm{ml}$ (a \& b) or PDGF-BB $20 \mathrm{ng} / \mathrm{ml}(\mathbf{c}-\mathbf{f})$ in the presence of INF- $\gamma$ [10-40 ng/mL], PFD [300-500 $\mu \mathrm{g} / \mathrm{mL}]$ or a combination of IFN- $\gamma /$ PFD for 1,3 and 5 days. Cell Titer $96^{\circledR}$ Non-Radioactive Cell Proliferation Assay (a-d) and cell counting using trypan blue staining and an automated Cellometer (e \& $\mathbf{f}$ ) revealed the proliferative response to both TGF- $\beta 1$ and PDGF-BB when compared with proliferation of the control, and both IFN- $\gamma$ and PFD alone inhibited TGF- $\beta 1$ - and PDGF-BB-induced proliferation in both NHLFs and IPF fibroblasts. The combination of both IFN- $\gamma$ and PFD treatment restrained cell proliferation to control levels. Data are presented as the means \pm SEMs of 3 independent experiments, with each experiment run in duplicate. ${ }^{* *} P<0.05$ vs. TGF- $\beta 1$ and ${ }^{\# \#} P<0.05$ vs. TGF- $\beta 1+$ vehicle [DMSO]

to control levels $(p>0.05$, Fig. 2a-f). The mitogenic effect of PDGF-BB was noticeably more potent in NHLFs compared to that in IPF fibroblasts, which is consistent with previous data demonstrating the different responses of normal and IPF fibroblasts to PDGF-BB and other growth factors $[33,43]$. The enhanced mitogenic effect of PDGF$\mathrm{BB}$ on normal compared to fibrotic fibroblasts in lung fibrosis models was attributed to the upregulated expression of PDGFR $\alpha$ [33].

IFN- $\gamma$ and PFD inhibit NHLF and IPF fibroblast migration in response to PDGF-BB with combined therapy exhibiting a synergistic effect

Both IFN- $\gamma(10-40 \mathrm{ng} / \mathrm{ml})$ and PFD $(300-500 \mu \mathrm{g} / \mathrm{ml})$ inhibited the migration of NHLFs and IPF fibroblasts in a dose-dependent manner in the presence of PDGF-BB $(20 \mathrm{ng} / \mathrm{ml})$ (Fig. 3). IFN- $\gamma(20-40 \mathrm{ng} / \mathrm{ml})$ significantly inhibited normal and IPF fibroblast migration compared to PFD $(300-500 \mu \mathrm{g} / \mathrm{ml})$ treatments. Furthermore, the combination of both IFN- $\gamma$ and PFD significantly inhibited fibroblast migration in response to PDGF-BB compared to that following individual treatment, indicating the possibly synergistic effect of combination treatment $(p<0.001$, Fig. 3$)$.
IFN- $\gamma$ and PFD synergistically downregulate the differentiation of normal and IPF fibroblasts into myofibroblasts

$\alpha$-SMA expression, a hallmark of fibroblast differentiation to myofibroblasts, was examined using immunoblotting and qPCR. Both IFN- $\gamma$ and PFD inhibited the TGF- $\beta 1$-induced expression of ACTA2 and $\alpha$-SMA protein in both NHLFs and IPF fibroblasts (Fig. 4a-d). The effect of IFN- $\gamma$ $(30-40 \mathrm{ng} / \mathrm{ml})$ was more potent than that of PFD (300$500 \mu \mathrm{g} / \mathrm{ml})$ in attenuating normal and IPF fibroblast differentiation ( $p<0.001$, Fig. 4a-d). Compared to individual drug treatment, the combination of IFN- $\gamma$ and PFD significantly inhibited TGF- $\beta 1$-induced ACTA2 and $\alpha$-SMA expression in NHLFs and IPF fibroblasts ( $p<0.01$, Fig. 4a-d).

Aberrant deposition of type I collagen-rich ECM is the typical phenotype of activated fibroblast/myofibroblasts in IPF lesions. Therefore, COL1A1 expression and the total soluble collagen content were examined using qPCR and a Sircol assay, respectively. Individual and combined IFN $-\gamma$ and PFD treatment inhibited TGF- $\beta 1$-induced COL1A1 expression in both NHLFs and IPF fibroblasts, with a significant difference noted between the effects of IFN- $\gamma$ and PFD treatment $(p<0.01$, Fig. 5a \& b) and individual and combined treatment $(p<0.001$, Fig. 5 a \& b). Similar to

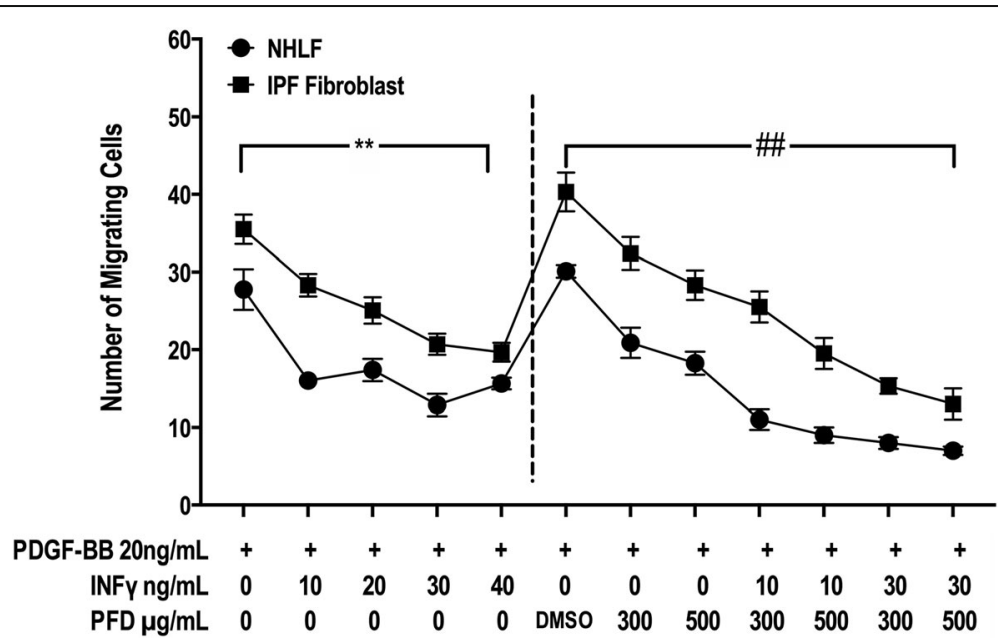

Fig. 3 INF- $\gamma$ and PFD inhibit the migration of NHLFs and IPF fibroblasts. Cell migration was assessed using a modified Boyden chamber in NHLFs and IPF fibroblasts treated with either INF- $\gamma[10-40 \mathrm{ng} / \mathrm{ml}]$, PFD [300-500 $\mu \mathrm{g} / \mathrm{ml}]$ or a combination of IFN- $/$ PFD in the upper chamber and PDGFBB $20 \mathrm{ng} / \mathrm{ml}$ used as a chemoattractant in the lower chamber for $24 \mathrm{~h}$. Data are presented as the means \pm SEMs of 3 independent experiments each run in duplicate. ${ }^{* *} P<0.05$ vs. control PDGF-BB and ${ }^{\# \#} P<0.05$ vs. PDGF-BB + vehicle [DMSO] 


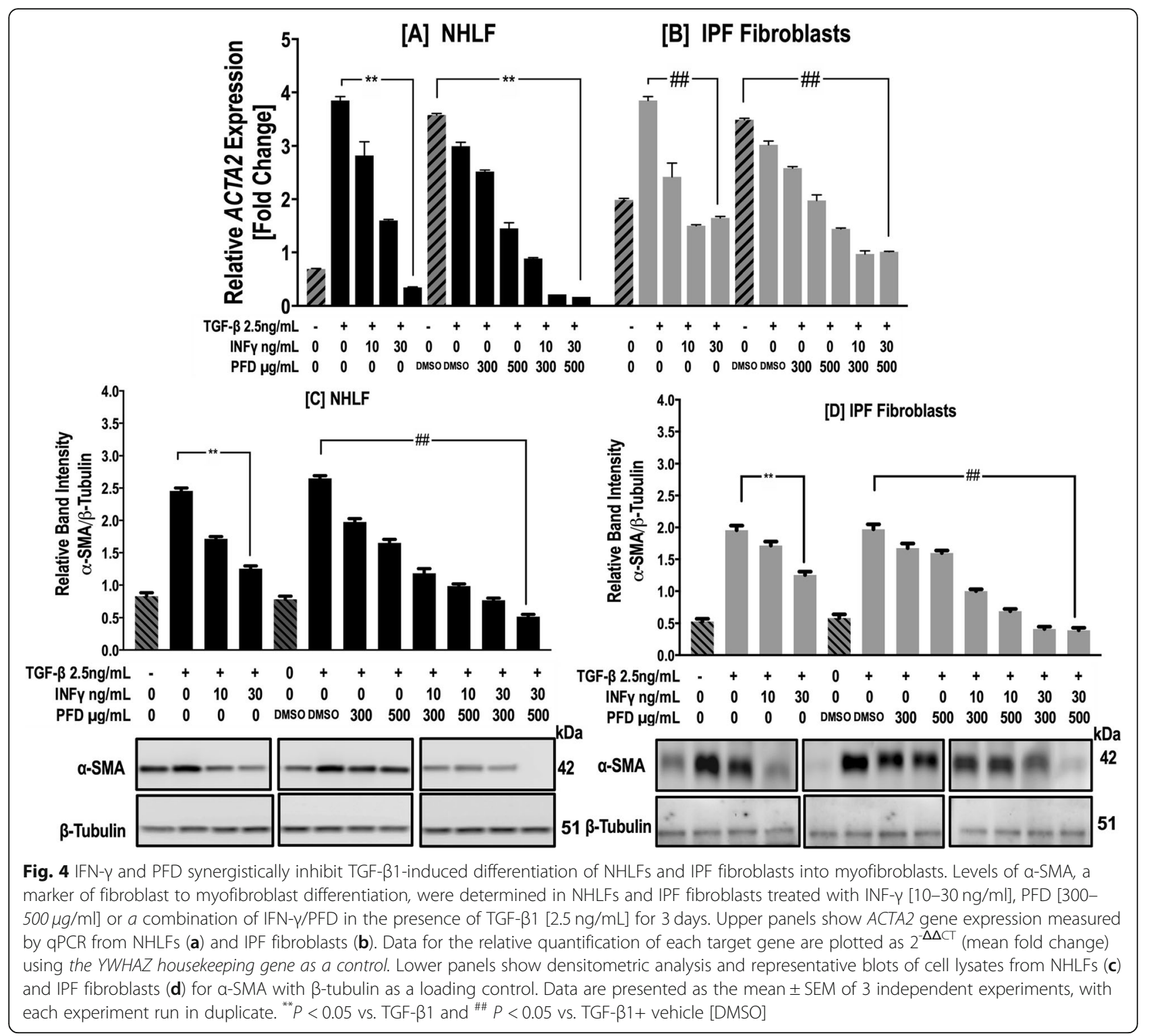

COL1A1 expression, secreted soluble collagen expression was consistently decreased by individual and combined IFN- $\gamma$ and PFD treatment, with a significant difference observed between IFN- $\gamma$ and PFD treatment and individual and combined treatment (Fig. 5c \& d).

IFN- $\gamma$ and PFD reverse the effect of TGF- $\beta 1$ on MMP/TIMP expression and release

MMP and TIMP expression and release were examined using $\mathrm{qPCR}$, immunoblot analysis and gelatin zymography. TGF- $\beta 1$ induced an increase in the intensity of the bands corresponding to proMMP-2 and active MMP-2. IFN- $\gamma$ and PFD individually and in combination significantly inhibited TGF- $\beta 1$-induced MMP-2 activation, as shown by gelatin zymography (Fig. 6a). Immunoblot analysis of supernatants with antibodies against MMP-1,
MMP-3 and MMP-7 revealed that culture in the presence of TGF- $\beta 1$ increased the intensity of the band corresponding to MMP-3, while the MMP- 1 and -7 bands were decreased by TGF- $\beta 1$ treatment. Individual and combined treatment with IFN- $\gamma$ and PFD induced a concentration-dependent decrease in the abundance of MMP-3 and increase in MMP-1 and MMP-7 in supernatants (Fig. 6b-d). Immunoblot analysis with antibodies against TIMP- 1 and -2 showed that TGF- $\beta 1$ increased the intensity of the band for TIMP-1 and decreased that of the band for TIMP-2, whereas PFD either alone or in combination with IFN- $\gamma$ induced a significant increase in the amounts of TIMP-1 and -2 (Fig. 6e \& f). IFN- $\gamma$ treatment had no significant effect on the intensity of the bands for TIMP-1 and -2 when compared to TGF$\beta 1$ treatment (Fig. 6e \& f). 

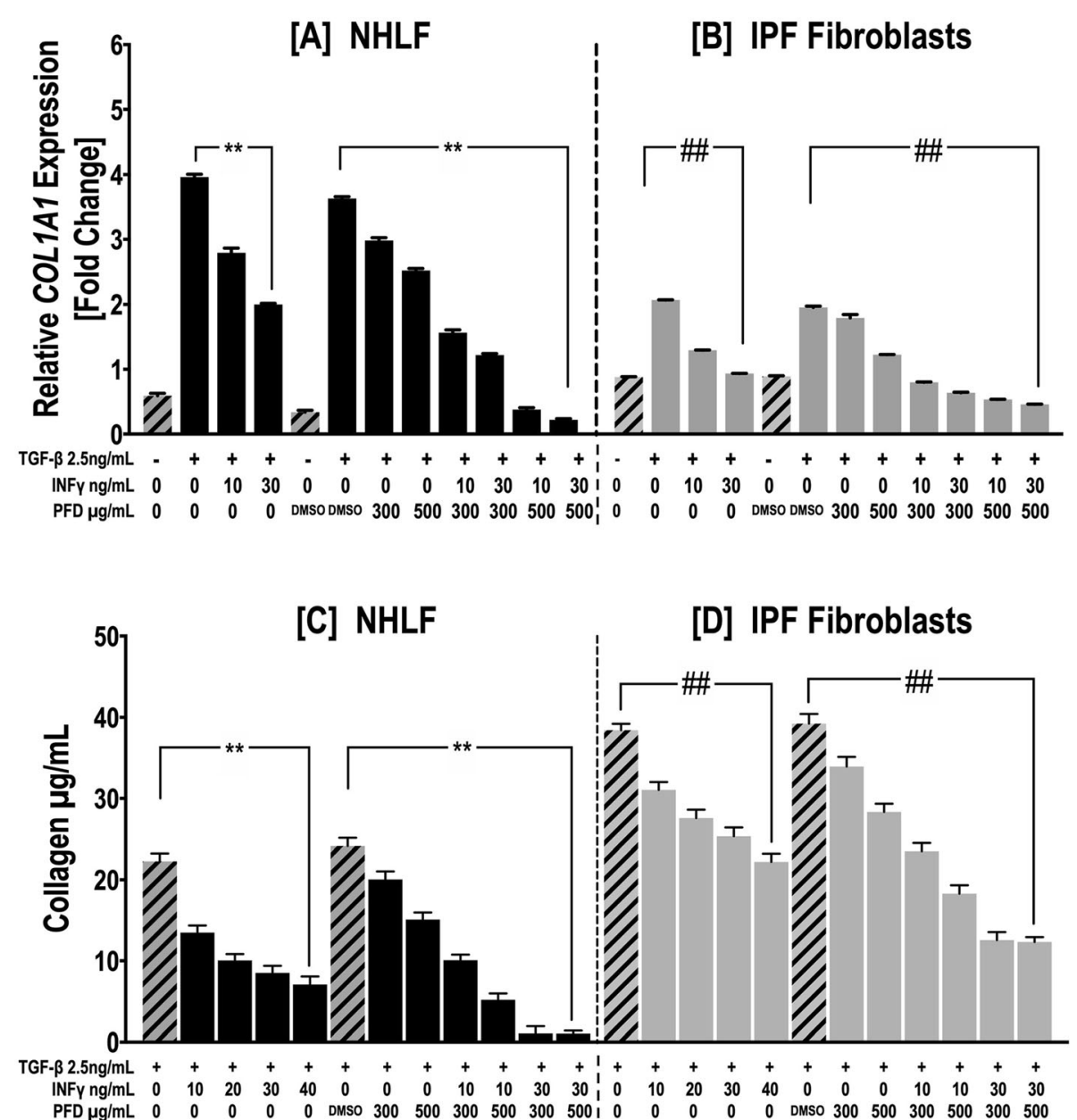

Fig. 5 IFN- $\gamma$ and PFD synergistically downregulate TGF - $\beta 1$-induced collagen expression and release. NHLFs and IPF fibroblasts were treated with INF$\gamma[10-40 \mathrm{ng} / \mathrm{mL}]$, PFD [300-500 $\mathrm{\mu g} / \mathrm{ml}]$ or a combination of IFN- $\gamma /$ PFD in the presence of TGF $-\beta 1[2.5 \mathrm{ng} / \mathrm{ml}]$ for 3 days. The upper panel shows COL1A1 gene expression measured by quantitative RT-PCR from NHLFs (a) and IPF fibroblasts (b). Data for the relative quantification of each target gene are plotted as $2^{-\triangle \triangle C T}$ (mean fold change) using the YWHAZ housekeeping gene as a control. The lower panel shows the collagen concentration in the conditioned media from NHLFs (c) and IPF fibroblasts (d) cultured for 3 days as measured by Sircol assay. Data are presented as the mean \pm SEM of 3 independent experiments, with each experiment run in duplicate. ${ }^{*} P<0.05$ vs. TGF- $\beta 1$ and ${ }^{\#} P<0.05$ vs. TGF- $\beta 1+$ vehicle [DMSO], respectively

Real-time PCR also showed that individual and combined treatment with IFN- $\gamma$ and PFD reversed the effects of TGF- $\beta 1$ on $M M P$ expression and resulted in a dosedependent decrease in $M M P 3$ and MMP9 (Fig. 7a \& b). In contrast, $M M P 1$ and $M M P 7$ mRNA expression was increased by IFN- $\gamma$ and PFD as well as the combination of both (Fig. $7 \mathrm{c}-\mathrm{d}$ ). Furthermore, TGF- $\beta 1$ treatment upregulated TIMP1 mRNA levels and downregulated TIMP2 mRNA levels, and only PFD treatment, either alone or in combination with IFN- $\gamma$, resulted in an increase in both TIMP1 and TIMP2 mRNA levels. IFN- $\gamma$ treatment had no significant effect on the TGF- $\beta 1$-induced regulation of TIMP1 and TIMP2 expression (Fig. 7e \& f).

\section{Discussion}

PFD and nintedanib are the only approved treatments for IPF. Both drugs have limited therapeutic value because they only slow the progression of fibrosis and produce systemic side effects. Although previous clinical trials of the systemic administration of IFN- $\gamma$ in IPF patients failed [21, 44, 45], our group has demonstrated that inhaled IFN- $\gamma$ is safe and without systemic effects, and inhaled IFN- $\gamma$ produced a measured improvement in the diffusion capacity in patients with IPF $[28,29]$. In this context, this study was designed to examine the in vitro antifibrotic effect of combined IFN- $\gamma$ and PFD treatment on NHLFs and IPF lung fibroblasts stimulated with either TGF- $\beta 1$ or PDGF-BB.

The present study demonstrates that both IFN $-\gamma$ and PFD attenuate the activation of NHLFs and IPF fibroblasts at several regulatory levels, including the inhibition of lung fibroblast proliferation, migration, differentiation to myofibroblasts and collagen secretion, after TGF- $\beta 1$ and PDGFBB stimulation. Compared to PFD, the effect of IFN- $\gamma$ in 


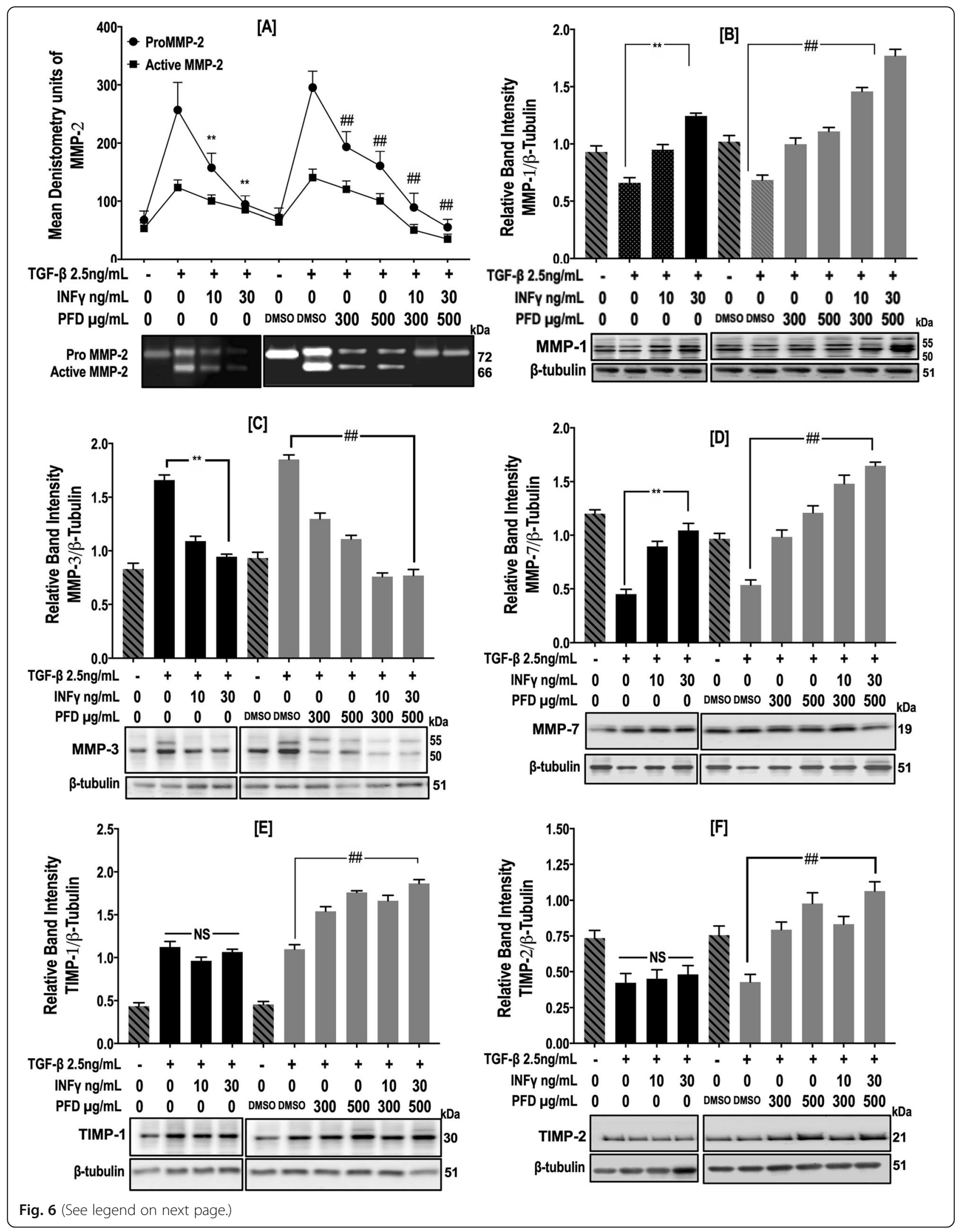


(See figure on previous page.)

Fig. 6 IFN- $\gamma$ and PFD reverse the effects of TGF- $\beta 1$ on MMP and TIMP release. NHLFs were treated with INF- $\boldsymbol{\gamma}[10-30 \mathrm{ng} / \mathrm{ml}]$, PFD [300-500 $\mu \mathrm{g} / \mathrm{ml}]$ or a combination of IFN- $\gamma /$ PFD in the presence of TGF $-\beta 1[2.5 \mathrm{ng} / \mathrm{ml}]$ for 3 days. Conditioned media was examined for MMP-2 using gelatin zymography, while MMP-1, MMP-3, MMP-7, TIMP-1 and TIMP-2 were examined using Western blotting with $\beta$-tubulin as a loading control. Data following densitometric analysis with a representative zymogram of MMP-2 (a) and blots for MMP-1 (b), MMP-3 (c), MMP-7 (d), TIMP-1 (e) and TIMP-2 (f) are shown. Data are presented as the mean \pm SEM of 3 independent experiments, with each experiment run in duplicate. ${ }^{* *} P<0.05$ vs. TGF- $\beta 1$ and ${ }^{\# \#} P<0.05$ vs. TGF- $\beta 1+$ vehicle [DMSO]

downregulating lung fibroblast differentiation to myofibroblasts is clearly more potent, as evidenced by a reduction in the expression of $\alpha$-SMA and collagen 1 and the attenuation of total collagen secretion. More importantly, the combination of both drugs had a possibly synergistic inhibitory effect on lung fibroblast proliferation, migration and differentiation. Furthermore, both IFN $-\gamma$ and PFD reversed the effect of TGF- $\beta 1$ on MMP- $1,-2,-3,-7$ and -9, while only PFD increased TIMP1 and TIMP2 expression and release. Collectively, these findings indicate that IFN- $\gamma$ has antifibrotic properties in vitro and that its combination with PFD has a possibly synergistic antifibrotic effect on NHLFs and IPF fibroblasts by altering the balance of MMPs and TIMPs.

Both IFN- $\gamma$ and PFD inhibited the TGF- $\beta 1$ - and PDGF-BB-induced proliferation of normal and IPF lung fibroblasts. Consistently, previous reports have shown that PFD and IFN- $\gamma$ modulate TGF- $\beta 1$-induced proliferation in not only normal lung fibroblasts [46-48] but also fibroblasts isolated from IPF patients [49, 50]. Moreover, the present study demonstrates that the combination of IFN- $\gamma$ and PFD has a synergistic attenuating effect on the TGF- $\beta 1$ - and PDGF-BB-induced proliferation of normal and IPF fibroblasts (Fig. 2a-f).

Here, we show that the INF- $\gamma$-induced downregulation of TGF- $\beta 1$-induced fibroblast differentiation to myofibroblasts was more potent than that induced by PFD (Fig. 4a-d). Previous reports showed that INF- $\gamma$ has $a$ strong inhibitory effect on the expression of $\alpha$-SMA in both in vivo [41, 51] and in vitro models of fibrosis. These findings suggested that INF- $\gamma$ exerts its antifibrotic effects in part via the inhibition of fibroblast differentiation to myofibroblasts [52, 53]. By inhibiting fibroblast differentiation to myofibroblasts, IFN- $\gamma$ treatment results in the inhibition of COL1A1 gene expression and total collagen secretion (Fig. 5a-d) in a manner similar to that suggested by previously reported data $[50,54,55]$. Importantly, we found that combined IFN- $\gamma$ and PFD significantly inhibited fibroblast differentiation and collagen expression and release. This finding suggests that both IFN- $\gamma$ and PFD carry out their antifibrotic actions via different mechanisms of action. PFD has been reported to inhibit fibroblast differentiation $[18,39,46,47,49,56]$ through dual hedgehog (Hh) pathway/TGF- $\beta 1$ inhibition by targeting the GLI2 protein [19]. In contrast, IFN- $\gamma$ inhibits fibroblast differentiation to myofibroblasts by antagonizing TGF- $\beta 1$ signaling in part via the upregulation of SMAD7 $[42,53]$ and the antagonistic interaction of SMAD and the JAK pathway at the nuclear p300/CBP level $[57,58]$.

Matrix metalloproteinases (MMPs) and their inhibitors (TIMPs) have been implicated in the pathogenesis of IPF. TGF- $\beta 1$ is known to regulate the expression of several MMPs in lung fibroblasts, which in turn can participate in TGF- $\beta 1$ activation [15, 59-61]. This study presents evidence that both IFN- $\gamma$ and PFD exert antifibrotic effects in part by reversing the effect of TGF- $\beta 1$ on MMPs and altering the balance of MMPs and TIMPs. Both IFN- $\gamma$ and PFD inhibit the TGF- $\beta 1$-induced activation of MMP-2 (Fig. 6a) and MMP9 gene expression (Fig. 7b). MMP-2 and -9 are known to activate latent ECM-bound TGF- $\beta 1$, contributing to an enhanced pool of active TGF- $\beta 1[15,60]$. MMP-9 is expressed by lung fibroblasts in fibroblastic foci [11] induced mainly by TGF- $\beta 1$ as part of a fibrogenic feedback loop in IPF lungs [62]. MMP-9 exerts its fibrotic effect by cleaving insulin-like growth factor (IGF)-binding protein-3 (IGFBP-3). IGFBP-3 serves as a downstream modulator of TGF- $\beta 1$ by inducing the production of syndecan-2 of fibroblasts $[63,64]$. Syndecan- 2 promotes cell signaling, proliferation, migration, cytoskeletal organization, cell-matrix interactions, and ECM assembly in lung fibroblasts [65]. Furthermore, both IFN- $\gamma$ and PFD inhibit TGF- $\beta 1$-induced MMP3 upregulation (Figs. 6c and 7a). MMP-3 expressed by lung fibroblasts plays a role in promoting EMT in lung epithelial cells via activating $\beta$-catenin signaling [12] and activating latent TGF- $\beta 1$ [66]. In support of our data, previous studies demonstrated the inhibitory effect of PFD on the expression of $M M P 3$ [20], MMP2 and $M M P 9$ [67, 68]. Other reports also demonstrated that IFN- $\gamma$ significantly attenuates IL-1-induced $M M P 1$ and $M M P 3$ production but has no effect on TIMP-1 production in rheumatoid arthritis-derived fibroblasts [40].

Both IFN- $\gamma$ and PFD reversed the TGF- $\beta 1$-induced inhibition of MMP7 and MMP1 expression. MMP-1 is significantly overexpressed in IPF lungs [11] and was shown to have in vitro protective activities against IPF fibroblasts [14]. Moreover, MMP-1 in lung epithelial cells increases their proliferation, migration, and expression of hypoxia-inducible factor- $1 \alpha[8,69]$. In contrast, MMP-7 carries out both pro- and antifibrotic functions 


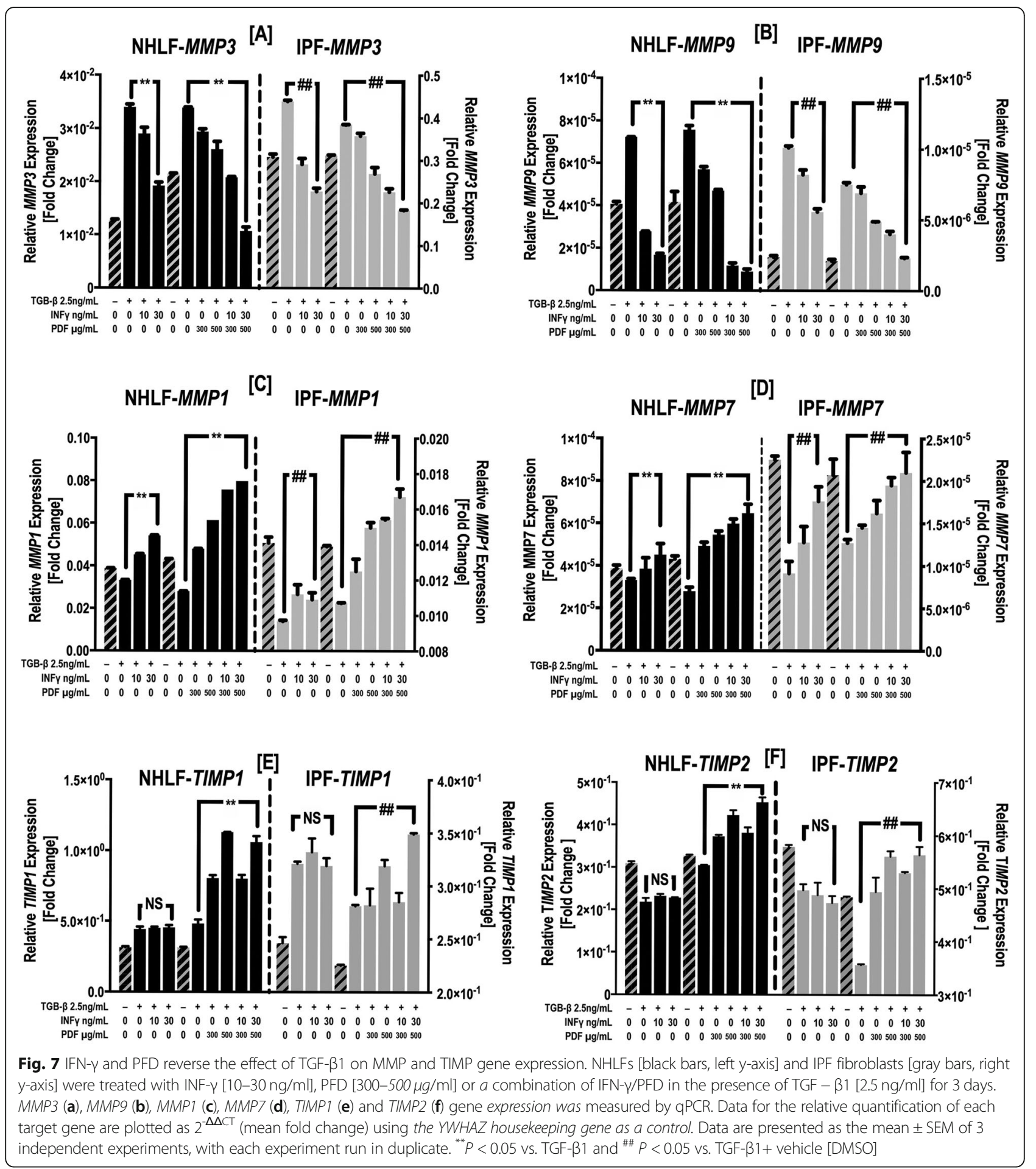

in lung fibrosis. Early on, MMP-7 functions by facilitating neutrophil influx and activation, leading to epithelial damage and an enhanced fibrotic environment. Then, epithelial-derived MMP-7 promotes resolution by attracting an influx of immunosuppressive leukocytes [70].

Interestingly, only PFD treatment increased TIMP1 and TIMP2 expression and release in normal and IPF fibroblasts (Figs. 6 and 7). TIMP-1 and -2 are highly induced during fibrosis in a number of animal models of lung fibrosis [71-73]. In fact, studies using mice genetically deficient for different TIMPs have demonstrated that TIMPs play many different roles, one of which is restricting ECM deposition and reducing ECM abundance by controlling cell function [74-77]. Although 
$T I M P 1^{-/-}$mice have pulmonary fibrotic responses to bleomycin similar to those of wild-type mice [78], inflammation is significantly increased in $T I M P 1^{-/-}$mice, suggesting that TIMP-1 plays a key role in restricting inflammation following lung injury [78]. TIMP-1 plays a similar role in the liver, as TIMP1 ${ }^{-/-}$mice had significantly increased injury, inflammation, and fibrosis following carbon tetrachloride-induced liver injury compared to wildtype mice [79].

Taken together, the data presented here provide evidence that IFN- $\gamma$ and PFD have different and potentially complementary antifibrotic effects on NHLFs and IPF lung fibroblasts. IFN- $\gamma$ exerts its antifibrotic effect by inhibiting fibroblast differentiation to myofibroblasts and ultimately inhibits collagen and $\alpha$-SMA expression possibly via counteracting the effects of TGF- $\beta 1$. In contrast, PFD exerts its antifibrotic effect on lung fibroblasts possibly by reversing the effect of TGF- $\beta 1$ on MMPs/ TIMPs. IFN- $\gamma$ and PFD in combination have a possibly synergistic effect on lung fibroblast activation and differentiation to myofibroblasts. Unfortunately, this in vitro study is still far from able to simulate complex situations such as the interactions between cell types and their compensatory mechanisms. The present findings support further investigation of the mechanisms underlying the antifibrotic effect of combined IFN- $\gamma$ and PFD therapy in an in vivo model of lung fibrosis.

\section{Conclusion}

The present study demonstrates that combined IFN- $\gamma$ and PFD treatment has possibly synergistic antifibrotic effects on NHLFs and IPF fibroblasts. Combination therapy with IFN- $\gamma$ and PFD may be a new and promising approach to the treatment of IPF and should be further explored in clinical trials.

\footnotetext{
Abbreviations

ACTA2: a-Smooth Muscle Actin; COL1A1: Collagen-1a1; ECM: Extracellular Matrix; EMT: Epithelial Mesenchymal Transformation; IFN- $\gamma$ : Interferon- $\gamma$; IGFBP-3: Insulin Growth Factor Binding Protein-3; IPF: Idiopathic Pulmonary Fibrosis; MMP: Matrix Metalloproteinase; NHLF: Normal Human Lung Fibroblast; PDGF-BB: Platelet Derived Growth Factor-BB; PFD: Pirfenidone; qPCR: Quantitative Polymerase Chain Reaction; TGF- $\beta 1$ : Transforming Growth Factor- $\beta 1$; TIMP: Tissue Inhibitors of Matrix Metalloproteinase; a-SMA: aSmooth Muscle Actin
}

\section{Acknowledgements}

We thank Lorraine Morra for help with imaging and figures. We thank Dr. Stanly Zucker for critical input and revision of the manuscript.

\begin{abstract}
Authors' contributions
TV and CX performed the experiments and analyzed the data; HD interpreted the results of the experiments, edited and revised the manuscript. GCS edited and revised the manuscript, and $\mathrm{NH}$ designed the research, prepared figures, analyzed data, drafted the manuscript and approved the final version of the manuscript. All authors read and approved the final manuscript.
\end{abstract}

\section{Funding}

This work has been supported in part by the Peter DeVito Memorial Foundation and Northport VAMC Research Funds.

\section{Availability of data and materials}

The datasets used and/or analyzed during the current study are available from the corresponding author on reasonable request.

Ethics approval and consent to participate

Not applicable

\section{Consent for publication}

Not applicable

\section{Competing interests}

The authors declare that they have no competing interests. New York University (NYU) and Stony Brook University (SBU) jointly hold patents on the treatment of lung disease with inhaled interferon gamma. These patents are licensed to InspiRx, Inc. Dr. Smaldone is a paid consultant to InspiRx, Inc.

Received: 10 September 2018 Accepted: 23 August 2019

Published online: 11 September 2019

\section{References}

1. Raghu G, Collard HR, Egan JJ, Martinez FJ, Behr J, Brown KK, Colby TV, Cordier JF, Flaherty KR, Lasky JA, et al. An official ATS/ERS/JRS/ALAT statement: idiopathic pulmonary fibrosis: evidence-based guidelines for diagnosis and management. Am J Respir Crit Care Med. 2011;183:788-824.

2. Raghu G. Idiopathic pulmonary fibrosis: guidelines for diagnosis and clinical management have advanced from consensus-based in 2000 to evidencebased in 2011. Eur Respir J. 2011;37:743-6.

3. King TE Jr, Schwarz MI, Brown K, Tooze JA, Colby TV, Waldron JA Jr, Flint A, Thurlbeck W, Cherniack RM. Idiopathic pulmonary fibrosis: relationship between histopathologic features and mortality. Am J Respir Crit Care Med. 2001;164:1025-32

4. Katzenstein AL, Myers JL. Idiopathic pulmonary fibrosis: clinical relevance of pathologic classification. Am J Respir Crit Care Med. 1998;157:1301-15.

5. Darby IA, Zakuan N, Billet F, Desmouliere A. The myofibroblast, a key cell in normal and pathological tissue repair. Cell Mol Life Sci. 2016;73:1145-57.

6. Scotton CJ, Chambers RC. Molecular targets in pulmonary fibrosis: the myofibroblast in focus. Chest. 2007;132:1311-21.

7. Willis $B C$, duBois RM, Borok Z. Epithelial origin of myofibroblasts during fibrosis in the lung. Proc Am Thorac Soc. 2006;3:377-82.

8. Herrera I, Cisneros J, Maldonado M, Ramirez R, Ortiz-Quintero B, Anso E, Chandel NS, Selman M, Pardo A. Matrix metalloproteinase (MMP)-1 induces lung alveolar epithelial cell migration and proliferation, protects from apoptosis, and represses mitochondrial oxygen consumption. J Biol Chem. 2013;288:25964-75.

9. Nkyimbeng T, Ruppert C, Shiomi T, Dahal B, Lang G, Seeger W, Okada Y, D'Armiento J, Gunther A. Pivotal role of matrix metalloproteinase 13 in extracellular matrix turnover in idiopathic pulmonary fibrosis. PLoS One. 2013;8:e73279.

10. Pardo A, Selman M. Matrix metalloproteases in aberrant fibrotic tissue remodeling. Proc Am Thorac Soc. 2006:3:383-8.

11. Selman M, Ruiz V, Cabrera S, Segura L, Ramirez R, Barrios R, Pardo A. TIMP-1, $-2,-3$, and -4 in idiopathic pulmonary fibrosis. A prevailing nondegradative lung microenvironment? Am J Physiol Lung Cell Mol Physiol. 2000;279:L562-74.

12. Yamashita CM, Dolgonos L, Zemans RL, Young SK, Robertson J, Briones N, Suzuki T, Campbell MN, Gauldie J, Radisky DC, et al. Matrix metalloproteinase 3 is a mediator of pulmonary fibrosis. Am J Pathol. 2011; 179:1733-45.

13. Zuo F, Kaminski N, Eugui E, Allard J, Yakhini Z, Ben-Dor A, Lollini L, Morris D, Kim Y, DeLustro B, et al. Gene expression analysis reveals matrilysin as a key regulator of pulmonary fibrosis in mice and humans. Proc Natl Acad Sci U S A. 2002;99:6292-7.

14. Pardo A, Cabrera S, Maldonado M, Selman M. Role of matrix metalloproteinases in the pathogenesis of idiopathic pulmonary fibrosis. Respir Res. 2016;17:23.

15. Loffek S, Schilling O, Franzke CW. Series "matrix metalloproteinases in lung health and disease": biological role of matrix metalloproteinases: a critical balance. Eur Respir J. 2011;38:191-208.

16. Craig VJ, Zhang L, Hagood JS, Owen CA. Matrix metalloproteinases as therapeutic targets for idiopathic pulmonary fibrosis. Am J Respir Cell Mol Biol. 2015;53:585-600. 
17. Tzouvelekis A, Bonella F, Spagnolo P. Update on therapeutic management of idiopathic pulmonary fibrosis. Ther Clin Risk Manag. 2015;11:359-70.

18. Hisatomi K, Mukae H, Sakamoto N, Ishimatsu Y, Kakugawa T, Hara S, Fujita H, Nakamichi S, Oku H, Urata Y, et al. Pirfenidone inhibits TGF-beta1-induced over-expression of collagen type I and heat shock protein 47 in A549 cells. BMC Pulm Med. 2012;12:24.

19. Didiasova M, Singh R, Wilhelm J, Kwapiszewska G, Wujak L, Zakrzewicz D, Schaefer L, Markart P, Seeger W, Lauth M, Wygrecka M. Pirfenidone exerts antifibrotic effects through inhibition of GLI transcription factors. FASEB J. 2017:31:1916-28.

20. Kadir SI, Wenzel Kragstrup T, Dige A, Kok Jensen S, Dahlerup JF, Kelsen J. Pirfenidone inhibits the proliferation of fibroblasts from patients with active Crohn's disease. Scand J Gastroenterol. 2016:51:1321-5.

21. King TE Jr, Albera C, Bradford WZ, Costabel U, Hormel P, Lancaster L, Noble PW, Sahn SA, Szwarcberg J, Thomeer M, et al. Effect of interferon gamma$1 \mathrm{~b}$ on survival in patients with idiopathic pulmonary fibrosis (INSPIRE): a multicentre, randomised, placebo-controlled trial. Lancet. 2009;374:222-8.

22. Raghu G, Brown KK, Bradford WZ, Starko K, Noble PW, Schwartz DA, King TE Jr. Idiopathic pulmonary fibrosis study G: a placebo-controlled trial of interferon gamma-1b in patients with idiopathic pulmonary fibrosis. N Engl J Med. 2004;350:125-33.

23. Jaffe HA, Buhl R, Mastrangeli A, Holroyd KJ, Saltini C, Czerski D, Jaffe HS, Kramer S, Sherwin S, Crystal RG. Organ specific cytokine therapy. Local activation of mononuclear phagocytes by delivery of an aerosol of recombinant interferongamma to the human lung. J Clin Invest. 1991;88:297-302.

24. Diaz KT, Skaria S, Harris K, Solomita M, Lau S, Bauer K, Smaldone GC, Condos $R$. Delivery and safety of inhaled interferon-gamma in idiopathic pulmonary fibrosis. J Aerosol Med Pulm Drug Deliv. 2012;25:79-87.

25. Poosti F, Bansal R, Yazdani S, Prakash J, Beljaars L, van den Born J, de Borst MH, van Goor H, Hillebrands JL, Poelstra K. Interferon gamma peptidomimetic targeted to interstitial myofibroblasts attenuates renal fibrosis after unilateral ureteral obstruction in mice. Oncotarget. 2016;7:54240-52.

26. Weng HL, Feng DC, Radaeva S, Kong XN, Wang L, Liu Y, Li Q, Shen H, Gao YP, Mullenbach $\mathrm{R}$, et al. IFN-gamma inhibits liver progenitor cell proliferation in HBV-infected patients and in 3,5-diethoxycarbonyl-1,4-dihydrocollidine diet-fed mice. J Hepatol. 2013;59:738-45.

27. Lindahl GE, Stock CJ, Shi-Wen X, Leoni P, Sestini P, Howat SL, Bou-Gharios G, Nicholson AG, Denton CP, Grutters JC, et al. Microarray profiling reveals suppressed interferon stimulated gene program in fibroblasts from scleroderma-associated interstitial lung disease. Respir Res. 2013;14:80.

28. Fusiak T, Smaldone GC, Condos R. Pulmonary fibrosis treated with inhaled interferon-gamma (IFN-gamma). J Aerosol Med Pulm Drug Deliv. 2015;28:406-10.

29. Skaria SD, Yang J, Condos R, Smaldone GC. Inhaled interferon and diffusion capacity in idiopathic pulmonary fibrosis (IPF). Sarcoidosis Vasc Diffuse Lung Dis. 2015;32:37-42.

30. Yanai H, Shteinberg A, Porat Z, Budovsky A, Braiman A, Ziesche R, Fraifeld VE. Cellular senescence-like features of lung fibroblasts derived from idiopathic pulmonary fibrosis patients. Aging (Albany NY). 2015;7:664-72.

31. Pechkovsky DV, Prele CM, Wong J, Hogaboam CM, McAnulty RJ, Laurent GJ, Zhang SS, Selman M, Mutsaers SE, Knight DA. STAT3-mediated signaling dysregulates lung fibroblast-myofibroblast activation and differentiation in UIP/IPF. Am J Pathol. 2012;180:1398-412.

32. Rojas-Valencia L, Montiel F, Montano M, Selman M, Pardo A. Expression of a 2.8-kb PDGF-B/c-sis transcript and synthesis of PDGF-like protein by human lung fibroblasts. Chest. 1995;108:240-5.

33. Hetzel M, Bachem M, Anders D, Trischler G, Faehling M. Different effects of growth factors on proliferation and matrix production of normal and fibrotic human lung fibroblasts. Lung. 2005;183:225-37.

34. Hasaneen NA, Cao J, Pulkoski-Gross A, Zucker S, Foda HD. Extracellular matrix metalloproteinase inducer (EMMPRIN) promotes lung fibroblast proliferation, survival and differentiation to myofibroblasts. Respir Res. 2016;17:17.

35. Hasaneen NA, Zucker S, Cao J, Chiarelli C, Panettieri RA, Foda HD. Cyclic mechanical strain-induced proliferation and migration of human airway smooth muscle cells: role of EMMPRIN and MMPs. FASEB J. 2005;19:1507-9.

36. Vandesompele J, De Preter K, Pattyn F, Poppe B, Van Roy N, De Paepe A, Speleman F. Accurate normalization of real-time quantitative RT-PCR data by geometric averaging of multiple internal control genes. Genome Biol. 2002;3:RESEARCH0034.

37. Stock CJ, Leoni P, Shi-wn X, Abraham DJ, Nicholson AG, Wells AU, Benzoni EA, Lindahl GE: Identification of stable housekeeping genes for real-time PCR in human pulmonary fibroblasts. Eur Respir J. 2011;38(Supp 55):3805.
38. Kwapiszewska G, Gungl A, Wilhelm J, Marsh LM, Thekkekara Puthenparampil H, Sinn K, Didiasova M, Klepetko W, Kosanovic D, Schermuly RT, et al. Transcriptome profiling reveals the complexity of pirfenidone effects in idiopathic pulmonary fibrosis. Eur Respir J. 2018; 52:1800564.

39. Knuppel L, Ishikawa Y, Aichler M, Heinzelmann K, Hatz R, Behr J, Walch A, Bachinger HP, Eickelberg O, Staab-Weijnitz CA. A novel antifibrotic mechanism of nintedanib and pirfenidone. Inhibition of collagen fibril assembly. Am J Respir Cell Mol Biol. 2017;57:77-90.

40. Page CE, Smale S, Carty SM, Amos N, Lauder SN, Goodfellow RM, Richards PJ, Jones SA, Topley N, Williams AS. Interferon-gamma inhibits interleukin1 beta-induced matrix metalloproteinase production by synovial fibroblasts and protects articular cartilage in early arthritis. Arthritis Res Ther. 2010;12:R49

41. Pittet B, Rubbia-Brandt L, Desmouliere A, Sappino AP, Roggero P, Guerret S, Grimaud JA, Lacher R, Montandon D, Gabbiani G. Effect of gamma-interferon on the clinical and biologic evolution of hypertrophic scars and Dupuytren's disease: an open pilot study. Plast Reconstr Surg. 1994;93:1224-35.

42. Ulloa L, Doody J, Massague J. Inhibition of transforming growth factor-beta/ SMAD signalling by the interferon-gamma/STAT pathway. Nature. 1999;397: 710-3.

43. Bonner JC. Regulation of PDGF and its receptors in fibrotic diseases. Cytokine Growth Factor Rev. 2004;15:255-73.

44. King TE Jr, Safrin S, Starko KM, Brown KK, Noble PW, Raghu G, Schwartz DA. Analyses of efficacy end points in a controlled trial of interferon-gamma1b for idiopathic pulmonary fibrosis. Chest. 2005;127:171-7.

45. Prasse A, Muller KM, Kurz C, Hamm H, Virchow JC Jr. Does interferongamma improve pulmonary function in idiopathic pulmonary fibrosis? Eur Respir J. 2003:22:906-11.

46. Conte E, Gili E, Fagone E, Fruciano M, lemmolo M, Vancheri C. Effect of pirfenidone on proliferation, TGF-beta-induced myofibroblast differentiation and fibrogenic activity of primary human lung fibroblasts. Eur J Pharm Sci. 2014;58:13-9.

47. Molina-Molina M, Machahua-Huamani C, Vicens-Zygmunt V, Llatjos R, Escobar I, Sala-Llinas E, Luburich-Hernaiz P, Dorca J, Montes-Worboys A. Anti-fibrotic effects of pirfenidone and rapamycin in primary IPF fibroblasts and human alveolar epithelial cells. BMC Pulm Med. 2018; 18:63.

48. Elias JA, Jimenez SA, Freundlich B. Recombinant gamma, alpha, and beta interferon regulation of human lung fibroblast proliferation. Am Rev Respir Dis. 1987;135:62-5.

49. Lehtonen ST, Veijola A, Karvonen H, Lappi-Blanco E, Sormunen R, Korpela S, Zagai U, Skold MC, Kaarteenaho R. Pirfenidone and nintedanib modulate properties of fibroblasts and myofibroblasts in idiopathic pulmonary fibrosis. Respir Res. 2016;17:14.

50. Narayanan AS, Whithey J, Souza A, Raghu G. Effect of gamma-interferon on collagen synthesis by normal and fibrotic human lung fibroblasts. Chest. 1992;101:1326-31.

51. Larrabee WF Jr. Keloid excision and recurrence prophylaxis via interdermal interferon-gamma injections. Laryngoscope. 1997;107:1284.

52. Tanaka K, Sano K, Tanaka K, Kobayashi M, Katsumura K, Ikeda T, Abe M. Demonstration of downregulation of alpha-smooth muscle actin in interferon-gamma-treated myofibroblast by a novel cell-capture enzyme immunoassay. Int Immunopharmacol. 2001;1:769-75.

53. Sobral LM, Montan PF, Martelli-Junior H, Graner E, Coletta RD. Opposite effects of TGF-beta1 and IFN-gamma on transdifferentiation of myofibroblast in human gingival cell cultures. J Clin Periodontol. 2007;34: 397-406.

54. Clark JG, Dedon TF, Wayner EA, Carter WG. Effects of interferon-gamma on expression of cell surface receptors for collagen and deposition of newly synthesized collagen by cultured human lung fibroblasts. J Clin Invest. 1989; 83:1505-11.

55. Gurujeyalakshmi G, Giri SN. Molecular mechanisms of Antifibrotic effect of interferon gamma in bleomycin-mouse model of lung fibrosis: downregulation of TGF- $\beta$ and procollagen I and III gene expression. Exp Lung Res. 1995;21:791-808.

56. Kurita Y, Araya J, Minagawa S, Hara H, Ichikawa A, Saito N, Kadota T, Tsubouchi K, Sato N, Yoshida M, et al. Pirfenidone inhibits myofibroblast differentiation and lung fibrosis development during insufficient mitophagy. Respir Res. 2017;18:114. 
57. Gu L, Zhu YJ, Guo ZJ, Xu XX, Xu WB. Effect of IFN-gamma and dexamethasone on TGF-beta1-induced human fetal lung fibroblastmyofibroblast differentiation. Acta Pharmacol Sin. 2004;25:1479-88.

58. Ghosh AK, Yuan W, Mori Y, Chen S, Varga J. Antagonistic regulation of type I collagen gene expression by interferon-gamma and transforming growth factor-beta. Integration at the level of p300/CBP transcriptional coactivators. J Biol Chem. 2001;276:11041-8.

59. Churg A, Zhou S, Wright JL. Series "matrix metalloproteinases in lung health and disease": matrix metalloproteinases in COPD. Eur Respir J. 2012;39:197-209.

60. Davey A, McAuley DF, O'Kane CM. Matrix metalloproteinases in acute lung injury: mediators of injury and drivers of repair. Eur Respir J. 2011;38:959-70.

61. Deshmukh HS, McLachlan A, Atkinson JJ, Hardie WD, Korfhagen TR, Dietsch M, Liu Y, Di PY, Wesselkamper SC, Borchers MT, Leikauf GD. Matrix metalloproteinase-14 mediates a phenotypic shift in the airways to increase mucin production. Am J Respir Crit Care Med. 2009;180:834-45.

62. Yu Q, Stamenkovic I. Cell surface-localized matrix metalloproteinase-9 proteolytically activates TGF-beta and promotes tumor invasion and angiogenesis. Genes Dev. 2000;14:163-76.

63. Pilewski JM, Liu L, Henry AC, Knauer AV, Feghali-Bostwick CA. Insulin-like growth factor binding proteins 3 and 5 are overexpressed in idiopathic pulmonary fibrosis and contribute to extracellular matrix deposition. Am J Pathol. 2005;166:399-407.

64. Ruiz XD, Mlakar LR, Yamaguchi Y, Su Y, Larregina AT, Pilewski JM, FeghaliBostwick CA. Syndecan-2 is a novel target of insulin-like growth factor binding protein-3 and is over-expressed in fibrosis. PLoS One. 2012;7:e43049.

65. Chen L, Klass C, Woods A. Syndecan-2 regulates transforming growth factorbeta signaling. J Biol Chem. 2004;279:15715-8.

66. Maeda S, Dean DD, Gomez R, Schwartz Z, Boyan BD. The first stage of transforming growth factor beta1 activation is release of the large latent complex from the extracellular matrix of growth plate chondrocytes by matrix vesicle stromelysin-1 (MMP-3). Calcif Tissue Int 2002;70:54-65.

67. Waller JR, Murphy GJ, Bicknell GR, Sandford R, Margolin SB, Nicholson ML. Pirfenidone inhibits early myointimal proliferation but has no effect on late lesion size in rats. Eur J Vasc Endovasc Surg. 2002;23:234-40.

68. Corbel M, Lanchou J, Germain N, Malledant Y, Boichot E, Lagente V. Modulation of airway remodeling-associated mediators by the antifibrotic compound, pirfenidone, and the matrix metalloproteinase inhibitor, batimastat, during acute lung injury in mice. Eur J Pharmacol. 2001;426:113-21.

69. Vaalamo M, Mattila $L$, Johansson N, Kariniemi AL, Karjalainen-Lindsberg ML, Kahari VM, Saarialho-Kere U. Distinct populations of stromal cells express collagenase-3 (MMP-13) and collagenase-1 (MMP-1) in chronic ulcers but not in normally healing wounds. J Invest Dermatol. 1997;109:96-101.

70. Giannandrea M, Parks WC. Diverse functions of matrix metalloproteinases during fibrosis. Dis Model Mech. 2014;7:193-203.

71. Dong J, Yu X, Porter DW, Battelli LA, Kashon ML, Ma Q. Common and distinct mechanisms of induced pulmonary fibrosis by particulate and soluble chemical fibrogenic agents. Arch Toxicol. 2016;90:385-402.

72. Hayashi T, Stetler-Stevenson WG, Fleming MV, Fishback N, Koss MN, Liotta LA, Ferrans VJ, Travis WD. Immunohistochemical study of metalloproteinases and their tissue inhibitors in the lungs of patients with diffuse alveolar damage and idiopathic pulmonary fibrosis. Am J Pathol. 1996;149:1241-56.

73. Madtes DK, Elston AL, Kaback LA, Clark JG. Selective induction of tissue inhibitor of metalloproteinase-1 in bleomycin-induced pulmonary fibrosis. Am J Respir Cell Mol Biol. 2001;24:599-607.

74. Jung KK, Liu XW, Chirco R, Fridman R, Kim HR. Identification of CD63 as a tissue inhibitor of metalloproteinase-1 interacting cell surface protein. EMBO J. 2006;25:3934-42.

75. Toricelli M, Melo FH, Peres GB, Silva DC, Jasiulionis MG. Timp1 interacts with beta-1 integrin and CD63 along melanoma genesis and confers anoikis resistance by activating $\mathrm{PI3-K}$ signaling pathway independently of Akt phosphorylation. Mol Cancer. 2013;12:22.

76. Qi JH, Ebrahem Q, Moore N, Murphy G, Claesson-Welsh L, Bond M, Baker A, Anand-Apte B. A novel function for tissue inhibitor of metalloproteinases-3 (TIMP3): inhibition of angiogenesis by blockage of VEGF binding to VEGF receptor-2. Nat Med. 2003;9:407-15.

77. Ebrahem Q, Qi JH, Sugimoto M, Ali M, Sears JE, Cutler A, Khokha R, Vasanji A, Anand-Apte B. Increased neovascularization in mice lacking tissue inhibitor of metalloproteinases-3. Invest Ophthalmol Vis Sci. 2011;52:6117-23.
78. Kim KH, Burkhart K, Chen P, Frevert CW, Randolph-Habecker J, Hackman RC, Soloway PD, Madtes DK. Tissue inhibitor of metalloproteinase-1 deficiency amplifies acute lung injury in bleomycin-exposed mice. Am J Respir Cell Mol Biol. 2005:33:271-9.

79. Wang H, Lafdil F, Wang L, Yin S, Feng D, Gao B. Tissue inhibitor of metalloproteinase 1 (TIMP-1) deficiency exacerbates carbon tetrachlorideinduced liver injury and fibrosis in mice: involvement of hepatocyte STAT3 in TIMP-1 production. Cell Biosci. 2011;1:14.

\section{Publisher's Note}

Springer Nature remains neutral with regard to jurisdictional claims in published maps and institutional affiliations.
Ready to submit your research? Choose BMC and benefit from:

- fast, convenient online submission

- thorough peer review by experienced researchers in your field

- rapid publication on acceptance

- support for research data, including large and complex data types

- gold Open Access which fosters wider collaboration and increased citations

- maximum visibility for your research: over $100 \mathrm{M}$ website views per year

At $\mathrm{BMC}$, research is always in progress.

Learn more biomedcentral.com/submissions 